\title{
EDITORIAL
}

\section{Emigration and immigration of mesenchymal cells: a multicultural airway wall}

\author{
A.G. Stewart
}

Chronic inflammatory disease is accompanied by structural changes that appear to relate to disease severity and duration, and are often considered to be poorly reversible, if at all. The processes underpinning the structural changes are varied, complex and not well understood. It is clear that these structural changes contribute to tissue dysfunction.

In asthma, remodelling comprises changes in all compartments of the airway wall, with the epithelium potentially orchestrating a persistent cycle of inflammatory injury and repair [1]. The epithelium is thought to influence the underlying mesenchymal cell network through the release of transforming growth factor- $\beta$ resulting in the activation of myofibroblasts that secrete excessive amounts of collagen and contribute to the burden of pro-inflammatory cytokines. Such changes in the superficial aspect of the airway recapitulate aspects of the pathogenesis of neointima formation, in which damage to the endothelium initiates a repair response that ultimately may compromise vessel function [2].

The most significant cellular component of the airway wall remodelling is an increase in the volume of airway smooth muscle (ASM), which is considered to play a dominant role in the consequences of the airway wall thickening for airway reactivity [3]. The mechanisms of the increase in volume of ASM remain ill-defined despite extensive investigation over the last 15 yrs. Hyperplasia of ASM is well evidenced, but there is also evidence for a more limited hypertrophy [4, 5]. The hyperplasia has been ascribed to proliferation in situ of ASM in response to growth factors and inflammatory mediators released during exacerbations of chronic asthma. Several investigations of antigen-induced airway inflammation in experimental animals, particularly those in Brown Norway rats, have demonstrated an increase in proliferation of ASM [6] resulting in an increase in the total number of ASM cells [7]. More recent evidence suggests that a decrease in the rate of ASM apoptosis may also contribute to the hyperplasia [8]. However, recent findings suggest the need to re-evaluate in situ proliferation as the major mechanism underlying the ASM hyperplasia. Neither we [9], nor others [10] have been able to detect increased rates of proliferation of ASM cells in biopsies using $\mathrm{Ki} 67$, proliferating cell nuclear antigen or cyclin D1 expression. It may be argued that in chronic asthma the rates of proliferation would be too small to detect an increase over the baseline level of cell turnover. Nevertheless, the lack of evidence for in situ proliferation of ASM in human asthmatic airways is consistent with the

Dept of Pharmacology, University of Melbourne, Parkville, Victoria, Australia.

Correspondence: A.G. Stewart, Dept of Pharmacology, University of Melbourne, Grattan Street, Parkville, Victoria 3010, Australia. Fax: 613 83440241. E-mail: astew@unimelb.edu.au

The author's work cited herein was supported by grants from National Health and Medical Research Council (NHMRC) and GlaxoSmithKline (UK). antiproliferative nature of the laminin and proteoglycan-rich extracellular matrix (ECM) surrounding the ASM cells in muscle bundles $[11,12]$. An alternative mechanism for the hyperplasia was identified in a biopsy study by GIZYCKI et al. [13], in which an increase in the number of myofibroblasts was detected within $24 \mathrm{~h}$ of segmental challenge of the airways. These myofibroblasts were considered to have differentiated from pre-existing fibroblasts, or more speculatively, to be the result of ASM migration and de-differentiation to the myofibroblast. Thus, hyperplasia of ASM could be the result of migration of mesenchymal cells from environments that are more conducive to proliferation, such as the collagenrich subepithelial region. This region would be bathed in growth factors and cytokines derived from resident fibroblasts, mast cells and epithelium, and from infiltrating leukocytes and or lymphocytes. A third, and equally intriguing, explanation of the rapid increase in myofibroblasts is offered by a study of allergen challenge, demonstrating the appearance of CD34+ procollagen expressing cells in the airway within $24 \mathrm{~h}$ [14]. In parallel studies in vitro, these cultured fibrocytes were shown to have the capacity to subsequently express $\alpha$-smooth muscle actin. In a murine model of allergic inflammation $\mathrm{CD} 34+$, pro-collagen I expressing fibroblasts could be recruited from a circulating pool of fibrocytes [14]. Regardless of the origins of the myofibroblasts, it seems reasonable to speculate that these cells could migrate towards the muscle bundle and differentiate further towards the smooth muscle pole of the mesenchymal phenotypic spectrum. Migration in and out of the ASM bundle would be expected to generate hetereogeneity of ASM phenotype. In a recent study in the Brown Norway allergen-induced inflammation and remodelling model, chronic inflammation was associated with a decrease in content of the $\alpha$-smooth muscle actin in the airway [15], consistent with the notion that some of the increase in ASM bulk in this model results from newly recruited and incompletely differentiated ASM.

The migration of mesenchymal cells, therefore, assumes importance in considering the mechanisms of airway wall remodelling and how these might be therapeutically targeted. The study by PARAMESWARAN et al. [16] in the current issue of the European Respiratory Journal adds to their earlier work showing that cys-Leukotrienes (cys-LTs) enhanced chemotactic responses to platelet-derived growth factor [17], by demonstrating that collagens III and V, as well as fibronectin, induce ASM migration by a process known as haptotaxis and that these responses are also enhanced by cys-LTs [16]. Several studies have investigated the pathways that underpin ASM chemotactic/chemokinetic responses. The upstream signalling mechanisms studied include: the activation of phosphoinositide-3-kinase, extracellular regulated kinase 1/2, src and p38 mitogen-activated kinase (MAPK) [18-21]. The latter kinase phosphorylates and activates MAPK-activated protein kinases 2 and 3, which phosphorylates heat shock 
protein 27, involved in cytoskeletal actin remodelling processes that are necessary for cell locomotion [21]. A number of these pathways are regulated by currently used anti-asthma agents and by stimuli for adenylate cyclase, such as prostaglandin $\mathrm{E}_{2}$ [22]. In addition, glucocorticoids, such as fluticasone propionate, synergise with salmeterol to suppress chemotaxis. Our recent investigations indicates that a collagen I-rich ECM reduces glucocorticoid regulation of migration as well as proliferation $[23,24]$, but $\beta_{2}$-adrenoceptor agonists, such as salmeterol, retain their efficacy in cells exposed to collagen I rich matrices [23].

The adhesion molecules/integrins subserving migration of different mesenchymal cell phenotypes have not been extensively characterised. Further investigation of the mechanisms of cell-matrix interactions are required to define the level of selective block of mesenchymal cell migration that may be therapeutically feasible. PARAMESWARAN et al. [16] provide evidence of the importance of the $\beta_{1}$ and $\alpha_{5}, \alpha_{\mathrm{v}}$ integrins in ASM migration, whereas integrins required for circulating fibrocytes to migrate into wounded tissue remain poorly defined. The authors emphasise that monomeric ECM molecules were used in their study as previous work suggests that fibrillar ECM may suppress chemotaxis [25]. These observations are similar to those that have been made in studies on the impact of ECM on vascular smooth muscle proliferation, in which fibrillar collagen suppresses and monomeric collagen enhances proliferation of mesenchymal cells [26]. In the inflamed airway wall the possible roles of ECM protein and proteoglycan degradation products should be examined. Other features of the migration response requiring attention include the possible selectivity of signal transduction pathways subserving chemotaxis, chemokinesis, haptotaxis and haptokinesis. Identification of chemotacticl haptotactic gradients required in situ for directed mesenchymal cell movement could prove to be difficult, especially as these gradients would need to reverse if smooth muscle does indeed migrate off the muscle bundle to proliferate and migrate back to add to the hyperplasia. Alternatively, the chemotactic signals may be mesenchymal phenotype-selective, allowing concurrent bi-directional mesenchymal cell migration; circulating fibrocytes are insensitive to chemoattractant actions of a number of chemokines, but show chemotactic responses to the $\mathrm{CXC7}$ and CCR4 ligands, stromal cellderived factor- $1 \alpha$ and secondary lymphoid-tissue chomokine, respectively [27]. There is increasing evidence that the phenotype of mesenchymal cells (both myofibroblasts and smooth muscle) derived from asthmatic airways and propagated in cell culture differs from that of cells derived from subjects without airways disease, showing increased ASM proliferation $[28,29]$ and increased airway fibroblast cytokine production $[30,31]$. Thus, it will be important to determine whether the migratory potential of asthmatic derived mesenchymal cells is altered.

Whilst the initial investigations of migration of mesenchymal cells in the context of airway/lung injury and repair raise more questions than answers, there is strong circumstantial evidence to support the contention that mesenchymal cell migration plays an important role in the dysregulated injury/ repair cycle that initiates and maintains the remodelled airway. Identification and enumeration of mesenchymal cells with a migratory phenotype in asthmatic airways would provide further impetus to this relatively new domain of airway wall remodelling research.

\section{References}

1. Holgate ST, Davies DE, Puddicombe S, et al. Mechanisms of airway epithelial damage: epithelial-mesenchymal interactions in the pathogenesis of asthma. Eur Respir $J$ 2003; 22: Suppl. 44, 24s-29s.

2. Stewart AG, Tomlinson PR, Wilson J. Airway wall remodelling in asthma: a novel target for the development of anti-asthma drugs. Trends Pharmacol Sci 1993; 14: 275279.

3. Lambert RK, Wiggs BR, Kuwano K, Hogg JC, Pare PD. Functional significance of increased airway smooth muscle in asthma and COPD. J Appl Physiol 1993; 74: 2771-2781.

4. Ebina M, Takahashi T, Chiba T, Motomiya M. Cellular hypertrophy and hyperplasia of airway smooth muscles underlying bronchial asthma: a 3-D morphometric study. Am Rev Respir Dis 1993; 148: 720-726.

5. Benayoun L, Druilhe A, Dombret MC, Aubier M, Pretolani M. Airway structural alterations selectively associated to severe asthma. Am J Respir Crit Care Med 2003; 167: 1360-1368.

6. Panettieri RA Jr, Murray RK, Bilgen G, Eszterhas AJ, Martin JG. Repeated allergen inhalations induce DNA synthesis in airway smooth muscle and epithelial cells in vivo. Chest 1995; 107: Suppl. 3, 94S-95S.

7. Xu KF, Vlahos R, Messina A, Bamford TL, Bertram JF, Stewart AG. Antigen-induced airway inflammation in the Brown Norway rat results in airway smooth muscle hyperplasia. J Appl Physiol 2002; 93: 1833-1840.

8. Martin JG, Ramos-Barbon D. Airway smooth muscle growth from the perspective of animal models. Respir Physiol Neurobiol 2003; 137: 251-261.

9. Mast A, Bamford TL, Wilson JW, et al. Smooth muscle area is increased in bronchial biopsies from steroid-resistant asthma. Am J Respir Crit Care Med 2003; 167: A33.

10. Benayoun L, Druilhe A, Dombret MC, Aubier M, Pretolani M. Airway structural alterations selectively associated with severe asthma. Am J Respir Crit Care Med 2003; 167: 13601368.

11. Hirst SJ, Twort $\mathrm{CH}$, Lee TH. Differential effects of extracellular matrix proteins on human airway smooth muscle cell proliferation and phenotype. Am J Respir Cell Mol Biol 2000; 23: 335-344.

12. Kilfeather SA, Tagoe S, Perez AC, Okona-Mensa K, Matin $\mathrm{R}$, Page CP. Inhibition of serum-induced proliferation of bovine tracheal smooth muscle cells in culture by heparin and related glycosaminoglycans. Br J Pharmacol 1995; 114 : 1442-1446.

13. Gizycki MJ, Adelroth E, Rogers AV, O'Byrne PM, Jeffery PK. Myofibroblast involvement in the allergen-induced late response in mild atopic asthma. Am J Respir Cell Mol Biol 1997; 16: 664-673.

14. Schmidt M, Sun G, Stacey MA, Mori L, Mattoli S. Identification of circulating fibrocytes as precursors of bronchial myofibroblasts in asthma. J Immunol 2003; 171: 380-389.

15. Moir LM, Leung SY, Eynott PR, et al. Repeated allergen inhalation induces phenotypic modulation of smooth muscle in bronchioles of sensitized rats. Am J Physiol Lung Cell Mol Physiol 2003; 284: L148-159.

16. Parameswaran K, Radford K, Zuo J, Janssen LJ, O'Byrne PM, Cox PG. Extracellular matrix regulates human airway smooth muscle cell migration. Eur Respir J 2004; 24: 545551.

17. Parameswaran K, Cox G, Radford K, Janssen LJ, Sehmi R, O'Byrne PM. Cysteinyl leukotrienes promote human airway smooth muscle migration. Am J Respir Crit Care Med 2002; 166: 738-742.

18. Goncharova EA, Ammit AJ, Irani C, et al. PI3K is required for proliferation and migration of human pulmonary vascular smooth muscle cells. Am J Physiol Lung Cell Mol Physiol 2002; 283: L354-363.

19. Goncharova EA, Vorotnikov AV, Gracheva EO, et al. Activation of $\mathrm{p} 38$ MAP-kinase and caldesmon phosphorylation are essential for urokinase-induced human smooth muscle cell migration. Biol Chem 2002; 383: 115-126. 
20. Goncharova EA, Goncharov DA, Eszterhas A, et al. Tuberin regulates p70 S6 kinase activation and ribosomal protein S6 phosphorylation. A role for the TSC2 tumor suppressor gene in pulmonary lymphangioleiomyomatosis (LAM). J Biol Chem 2002; 277: 30958-30967.

21. An SS, Fabry B, Mellema M, et al. 2004. Role of heat shock protein 27 in cytoskeletal remodeling of the airway smooth muscle cell. J Appl Physiol 2004; 96: 1701-1713.

22. Goncharova EA, Billington CK, Irani C, et al. Cyclic AMPmobilizing agents and glucocorticoids modulate human smooth muscle cell migration. Am J Respir Cell Mol Biol 2003; 29: 19-27.

23. Bonacci JV, Harris T, Stewart AG. Complementary actions of glucocorticoids and $\beta_{2}$-adrenoceptor agonists on airway smooth muscle functions involved in airway wall remodelling. Am J Respir Crit Care Med 2004; 169: A195.

24. Bonacci JV, Harris T, Wilson JW, Stewart AG. Collageninduced resistance to glucocorticoid anti-mitogenic actions: a potential explanation of smooth muscle hyperplasia in the asthmatic remodelled airway. Br J Pharmacol 2003; 138: 1203-1206.

25. Tanaka S, Koyama H, Ichii $\mathrm{T}$, et al. Fibrillar collagen regulation of plasminogen activator inhibitor-1 is involved in altered smooth muscle cell migration. Arterioscler Thromb Vasc Biol 2002; 22: 1573-1578.

26. Koyama H, Raines EW, Bornfeldt KE, Roberts JM, Ross R. Fibrillar collagen inhibits arterial smooth muscle proliferation through regulation of Cdk2 inhibitors. Cell 1996; 87: 1069-1078.

27. Hashimoto N, Jin H, Liu T, Chensue SW, Phan SH. Bone marrow-derived progenitor cells in pulmonary fibrosis. $J$ Clin Invest 2004; 113: 243-252.

28. Johnson PR, Roth M, Tamm M, et al. Airway smooth muscle cell proliferation is increased in asthma. Am J Respir Crit Care Med 2001; 164: $474-477$.

29. Chambers LS, Black JL, Ge Q, et al. PAR-2 activation, PGE2, and COX-2 in human asthmatic and nonasthmatic airway smooth muscle cells. Am J Physiol Lung Cell Mol Physiol 2003; 285: L619-627.

30. Dube J, Chakir J, Laviolette $\mathrm{M}$, et al. In vitro procollagen synthesis and proliferative phenotype of bronchial fibroblasts from normal and asthmatic subjects. Lab Invest 1998; 78: 297-307.

31. Zhang S, Smartt H, Holgate ST, Roche WR. Growth factors secreted by bronchial epithelial cells control myofibroblast proliferation: an in vitro co-culture model of airway remodeling in asthma. Lab Invest 1999; 79: 395-405. 